\title{
Effects of land use and cover change on terrestrial carbon stocks in urbanized areas: a study from Changzhou, China
}

\author{
Yu Tao a , Feng Li ${ }^{\text {a, * }}$, Rusong Wang a , Dan Zhao ${ }^{\mathrm{b}}$ \\ a State Key Laboratory of Urban and Regional Ecology, Research Center for Eco-Environmental Sciences, Chinese Academy of Sciences, 18 Shuangqing Road, \\ Haidian District, Beijing 100085, China \\ ${ }^{\mathrm{b}}$ Beijing Municipal Institute of City Planning \& Design, 60 Nanlishi Street, Xicheng District, Beijing 100045, China
}

\section{A R T I C L E I N F O}

Article history:

Received 22 February 2014

Received in revised form 6 July 2014

Accepted 22 July 2014

Available online 2 August 2014

\section{Keywords:}

Carbon stocks

Land use and cover change

Soil sealing

Urbanization

\begin{abstract}
A B S T R A C T
Land use and cover change is the key factor affecting terrestrial carbon stocks and their dynamics not only in regional ecosystems but also in urbanized areas. Using the typical fast-growing city of Changzhou, China as a case study, this paper explored the relationships between terrestrial carbon stocks and land cover within an urbanized area. The main objectives were to assess variation in biomass and soil carbon stocks across terrestrial land covers with different intensities of urban development, and quantify spatial distribution and dynamic variation of terrestrial carbon stocks in response to urban land use and cover change. On the basis of accurate spatial datasets derived from a series of Landsat TM images during the years 1986 to 2011 and reliable estimates of urban biomass and soil carbon stocks using the InVEST model, our results showed that carbon stocks per unit area in terrestrial land covers decreased with increasing intensity of urban development. Urban land use and cover change and sealing of the soil surface created hotspots for losses in carbon stocks. Total carbon stocks in Changzhou decreased by about $30 \%$ during the past 25 years, representing a 1.5\% average annual decrease. We suggested potential policy measures to mitigate negative effects of land use and cover change on carbon stocks in urbanized areas.
\end{abstract}

(C) 2014 Elsevier Ltd. All rights reserved.

\section{Introduction}

The impacts of urbanization extend over large areas even though the areal percentage of urban land in regional land cover matrices is typically quite small (Wade et al., 2009). Many aspects of environmental change at regional and global scales, including carbon dioxide emissions, have been attributed to urban areas (Flysjo et al., 2012; Seto et al., 2012; Castanheira and Freire, 2013; Hortenhuber et al., 2014). A large body of literature has been published on urbanization and its impact on carbon emissions from industrial energy use, transportation, household consumption, etc (Liu et al., 2011; Sun et al., 2014; Wang and Yang, 2014). Many of these studies have also addressed carbon accounting for anthropogenic components of urban areas such as buildings, landfills and urban road systems using Input-Output analyses, material flows and life cycle assessment (Dhakal, 2010; Guo et al., 2014).

On the other hand, urbanized areas have been found to foster and provide valuable ecosystem services such as carbon stocks in

\footnotetext{
* Corresponding author. Tel.: +861062849103.

E-mail addresses: taoyu880216@126.com (Y. Tao), lifeng@rcees.ac.cn (F. Li) wangrs@rcees.ac.cn (R.S. Wang), zhaodan718100@163.com (D. Zhao).
}

natural pools that encompass urban biomass and soil (Strohbach and Haase, 2012). Whilst obviously small in relative magnitude compared to carbon emissions from fossil fuels consumption, the size of natural carbon pools nevertheless appears to be substantial (Davies et al., 2011; Liu and Li, 2012). This has been indicated by the results of a recent study from Churkina et al. (2010) showing that urban areas can store as much carbon per unit area as natural ecosystems across the conterminous United States, and more than $80 \%$ of this carbon is attributed to urban biomass and soil (i.e., only a small proportion of carbon is stored in anthropogenic pools). Churkina et al. (2010) have also suggested that in the coming decades, more terrestrial carbon stocks will be contained in human settlements, simply because urbanized areas are continuing to expand at an unprecedented rate. However, considering that biomass and soil carbon stocks vary across multiple land covers within urbanized areas, such rapid growth in urban carbon reservoirs driven by land use and cover change is often at the cost of even more severe reduction in carbon stocks from peri-urban and rural areas, which become the main cause of decreased carbon sequestration potential in regional ecosystems (Borjesson and Tufvesson, 2011; Hutyra et al., 2011a; Ponsioen and Blonk, 2012; Zhang et al., 2012). Therefore, land use and cover change can be 
another key factor affecting spatial distribution and dynamic variation of biomass and soil carbon stocks in urbanized areas. However, few studies have addressed this important issue compared to the large volume of literature on anthropogenic carbon pools and emissions from fossil fuels consumption.

Using the typical fast-growing city of Changzhou, China as a case study, this paper explores the relationships between terrestrial carbon stocks and land cover within an urbanized area. The main objectives are to (1) assess variation in biomass and soil carbon stocks across terrestrial land covers with different intensities of urban development, (2) quantify spatial distribution and dynamic variation of terrestrial carbon stocks in response to urban land use and cover change, and (3) discuss some measures for preservation of carbon stocks in urbanized areas.

\section{Materials and methods}

\subsection{Study area}

Changzhou is located in southern Jiangsu Province, on the upper Yangtze River Delta $\left(31^{\circ} 09^{\prime}-32^{\circ} 04^{\prime} \mathrm{N}, 119^{\circ} 08^{\prime}-120^{\circ} 12^{\prime} \mathrm{E}\right)$. It is characterized by flat landforms and warm cloudy weather typical of the northern subtropical monsoon climate zone. The cultivated soils on its periphery are mainly paddy soil, and the major vegetation types are mid-subtropical evergreen and broadleaf forest and northern subtropical mixed stands of deciduous and evergreen forest with dominant species such as masson pine (Pinus massoniana), China fir (Cunninghamia lanceolata), oaks (Quercus spp.) and bamboos (Phyllostachys Sieb. et Zucc.). The area of Changzhou has expanded since the mid-1980s, from $187 \mathrm{~km}^{2}$ in the 1980 s to $1871 \mathrm{~km}^{2}$ by the 2000s, which is now comprised of five municipal districts with Tianning, Zhonglou and Qishuyan districts in the urban center, and Xinbei and Wujin districts in peri-urban areas (Fig. 1).

\subsection{Classification of land use and land cover}

Primary data were derived from a series of Landsat TM images from 1986 to 2011 at a $30 \mathrm{~m}$ resolution. Other supplementary data included a 1:2000 topographic map and administrative maps provided by the Planning and Designing Institute of Changzhou for visual interpretation of land covers. The topographic map was used to differentiate hilly area from flat area in Changzhou. Typical land covers in the study area were classified as forest land (timbered hilly area), green open spaces (vegetated flat area), urban land and water area. We conducted a kappa test using historical land use
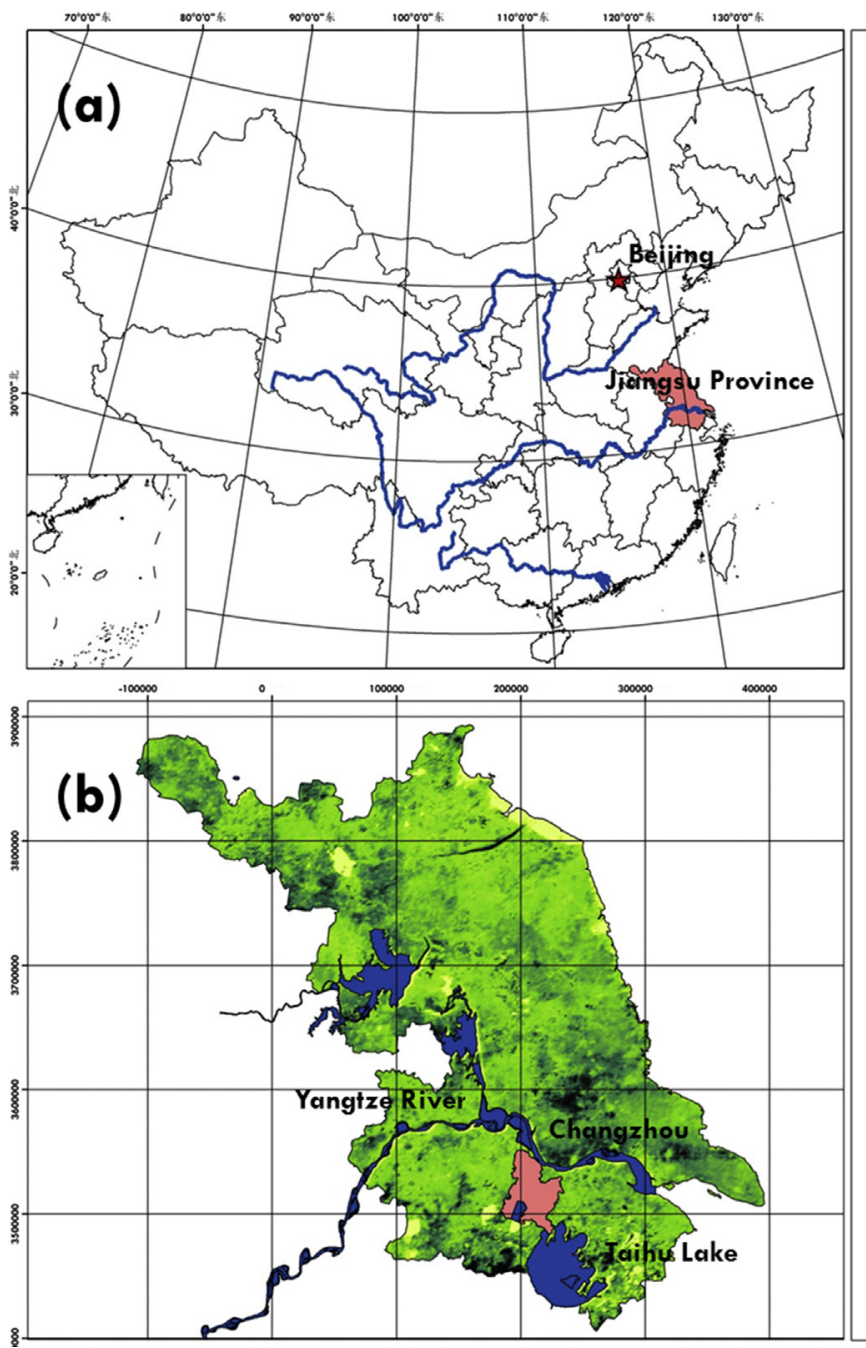

(c)

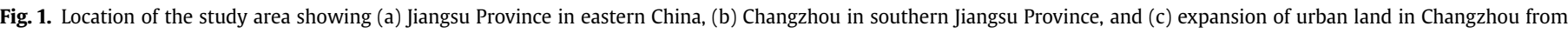
1986 to 2011. 
maps, ground-based reference information and random sampling to test the quality of the classification results. The kappa values averaged 0.82 for the six classified images. All of the values were greater than 0.7 , which is the minimal requirement for a satisfactory classification.

\subsection{Estimation of terrestrial carbon stocks in different land covers}

Carbon stocks in terrestrial land covers were estimated using the InVEST (Integrated Valuation of Environmental Services and Tradeoffs) Carbon Storage and Sequestration model developed by the Natural Capital Project team (Daily et al., 2009; Tallis et al., 2013). For each land cover type, the model requires an estimate of the amount of carbon stored in the four basic carbon pools: aboveground and belowground biomass, litter layer and soil organic matter (Chan et al., 2006; Nelson et al., 2009; Goldstein et al., 2012; Qiu and Turner, 2013). The model then applies these estimates to the land use and land cover map to produce a map of carbon stocks in each grid cell and across the whole study area. The model is also applied to a historical land cover map and the current land cover map to calculate the net change in carbon stocks over time map unit by map unit, assuming that the only changes in carbon stocks are due to changes from one land cover to another (i.e., any grid cell that does not change its land cover will have a sequestration and loss value of 0 over time).

In this study, forest inventory data collected by the Agricultural and Forestry Bureau of Changzhou provided information on the area and distribution of various types of forest in forest land and green open spaces. Biomass carbon stocks per unit area in these types of forest were derived from the results of several local studies (WDC, 2006; Zhao et al., 2010; Cantarello et al., 2011). The estimated biomass carbon stocks in forest land and green open spaces were at some fixed storage level equal to the area-weighted average of reported storage levels of each type of forest within that land cover. A soil map covering the study area was also used (HWSD, 2008), and we summed soil organic carbon for the upper $100 \mathrm{~cm}$ in each grid cell and averaged by land cover to estimate soil carbon stocks in forest land and green open spaces.

Urban forest patches such as urban parks and green belts were classified as green open spaces in this study, while the urban land of Changzhou was covered by extensive impervious surfaces, on which biomass carbon stocks were negligible. To assess the impact of extensive impervious surfaces in urban land on soil organic carbon stocks, we incorporated the results of some recent studies from Zhao et al. (2012) and Raciti et al. (2012). According to their results, carbon stocks in soils under urban land averaged about 50\% of the values in forest soils at different depths. This was probably caused by removal of the topsoil during the development process and interrupted accumulation of organic carbon in sealed soils that led to both actual and potential losses in soil carbon stocks. We did not calculate carbon stored in water area, in which the InVEST model produced high uncertainty. As all estimates were drawn from empirical studies, we did not perform accuracy assessment for carbon stocks.

\section{Results}

\subsection{Estimated biomass and soil carbon stocks in different land covers}

Average carbon densities in terrestrial land covers were found to decrease with increasing intensity of urban development in the study area: forest land had $78.85 \mathrm{MgC} \mathrm{ha}^{-1}$, green open spaces had 73.82 $\mathrm{Mg} \mathrm{C} \mathrm{ha}^{-1}$ and urban land had 25.23 $\mathrm{Mg} \mathrm{C} \mathrm{ha}^{-1}$ (Table 1). The estimated carbon densities in soil organic matter averaged from 25.23 to $68.91 \mathrm{Mg} \mathrm{C} \mathrm{ha}^{-1}$ in different land covers, the greatest of the four basic carbon pools, followed by aboveground (3.18 to $18.87 \mathrm{Mg} \mathrm{C} \mathrm{ha}^{-1}$ ) and belowground biomass (1.42 to $5.88 \mathrm{MgC} \mathrm{ha}^{-1}$ ). Carbon stored in litter layer organic matter was the smallest component, only 0.31 to $3.54 \mathrm{Mg} \mathrm{C} \mathrm{ha}^{-1}$.

Despite distinct differences in biomass carbon stocks between forest land and green open spaces in the study area, the amount of carbon stored in forest soils was relatively small compared to soil carbon stored in green open spaces (Table 1). This was in part a result of forest structure mainly comprised of young and middleaged trees, which resulted in restrained accumulation of organic carbon in forest soils. Conversely, irrigated paddy fields, which store a substantial amount of soil organic carbon, covered a large area of green open spaces, making them more abundant in soil carbon stocks than immature forests.

\subsection{Effects of land use and cover change on carbon stocks from 1986 to 2011}

According to the land use and land cover interpreted from remote sensing images, the urban land of Changzhou expanded rapidly from about $85 \mathrm{~km}^{2}$ in 1986 to $800 \mathrm{~km}^{2}$ in 2011, while the areal percentage of urban land in terrestrial land covers increased from about $5 \%$ to $50 \%$ during the same period. The area covered by green open spaces decreased from about $1500 \mathrm{~km}^{2}(90 \%)$ in 1986 to $800 \mathrm{~km}^{2}(50 \%)$ in 2011 . This dramatic shift in land covers in the study area led to increased carbon stocks in urban land from $0.21 \mathrm{Tg} C$ to $2.02 \mathrm{Tg} C$ with average annual growth of $9.4 \%$, and decreased carbon stocks in green open spaces from $11.16 \mathrm{Tg} C$ to

Table 1

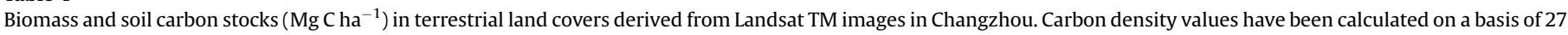
studies undertaken in Changzhou (CZ), southern Jiangsu Province (SJ), Jiangsu Province (J), China (C) and worldwide (W).

\begin{tabular}{|c|c|c|c|c|c|c|c|c|c|c|c|c|c|c|c|c|}
\hline \multirow[t]{2}{*}{ Land covers } & \multicolumn{3}{|c|}{$\begin{array}{l}\text { Aboveground carbon } \\
\text { stocks }(\mathrm{Mg} \mathrm{C} \mathrm{ha-1)}\end{array}$} & \multicolumn{3}{|c|}{$\begin{array}{l}\text { Belowground carbon } \\
\text { stocks ( } \mathrm{Mg} \mathrm{C} \mathrm{ha-1)}\end{array}$} & \multicolumn{3}{|c|}{$\begin{array}{l}\text { Litter layer carbon } \\
\text { stocks ( } \mathrm{Mg} \mathrm{C} \mathrm{ha-1)}\end{array}$} & \multicolumn{3}{|c|}{$\begin{array}{l}\text { Soil carbon } \\
\text { stocks }(\mathrm{Mg} \mathrm{C} \mathrm{ha-1)}\end{array}$} & \multicolumn{3}{|c|}{$\begin{array}{l}\text { Total carbon } \\
\text { stocks }(\mathrm{Mg} \mathrm{C} \mathrm{ha-1)}\end{array}$} & \multirow[t]{2}{*}{ References $^{\mathrm{a}}$} \\
\hline & $\bar{X}$ & $X_{\min }$ & $X_{\max }$ & $\bar{X}$ & $X_{\min }$ & $X_{\max }$ & $\bar{X}$ & $X_{\min }$ & $X_{\max }$ & $\bar{X}$ & $X_{\min }$ & $X_{\max }$ & $\bar{X}$ & $X_{\min }$ & $X_{\max }$ & \\
\hline Forest land & 18.87 & 15.08 & 21.95 & 5.88 & 4.70 & 6.84 & 3.54 & 2.50 & 3.72 & 50.56 & 40.02 & 63.51 & 78.85 & 62.30 & 96.02 & $\begin{array}{l}1^{\mathrm{CZ}}, 2^{\mathrm{CZ}}, 3^{\mathrm{CZ}}, 4^{\mathrm{SJ}}, 5^{\mathrm{SJ}}, 6^{\mathrm{SJ}}, 7^{\mathrm{C}}, 8^{\mathrm{SJ}}, 9^{\mathrm{SJ}} \\
10^{\mathrm{CZ}}, 11^{\mathrm{C}}, 12^{\mathrm{SJ}}, 13^{\mathrm{SJ}}, 14^{\mathrm{J}}, 15^{\mathrm{J}}, 16^{\mathrm{J}}\end{array}$ \\
\hline $\begin{array}{l}\text { Green open } \\
\text { spaces }\end{array}$ & 3.18 & 2.84 & 3.45 & 1.42 & 1.32 & 1.50 & 0.31 & 0.22 & 0.33 & 68.91 & 48.30 & 75.91 & 73.82 & 52.68 & 81.19 & $\begin{array}{l}1^{\mathrm{CZ}}, 2^{\mathrm{CZ}}, 3^{\mathrm{CZ}}, 7^{\mathrm{C}}, 8^{\mathrm{SJ}}, 9^{\mathrm{SJ}}, 10^{\mathrm{CZ}}, 11^{\mathrm{C}} \\
17^{\mathrm{SJ}}, 18^{\mathrm{C}}, 19^{\mathrm{C}}, 20^{\mathrm{C}}, 21^{\mathrm{CZ}}, 22^{\mathrm{W}}, 23^{\mathrm{J}}, \\
24^{\mathrm{J}}, 25^{\mathrm{J}}, 26^{\mathrm{J}}\end{array}$ \\
\hline Urban land & 0 & 1 & 1 & 0 & 1 & 1 & 0 & 1 & 1 & 25.23 & 17.59 & 36.04 & 25.23 & 17.59 & 36.04 & $10^{\mathrm{CZ}}, 11^{\mathrm{C}}, 12^{\mathrm{SJ}}, 13^{\mathrm{SJ}}, 14^{\mathrm{J}}, 15^{\mathrm{J}}, 16^{\mathrm{J}}, 27^{\mathrm{C}}$ \\
\hline
\end{tabular}

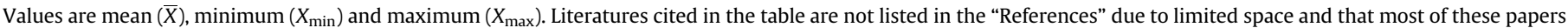
were published in Chinese journals (See Appendix A. for Supplementary data).

a 1. Tang et al., (2005); 2. Tang et al., (2009); 3. Zhang et al., (2011); 4. Wang et al., (2011); 5. Jiang et al. (2002); 6. Wu et al., (2002); 7. Fang et al., (1996); 8. Yang and Jiang

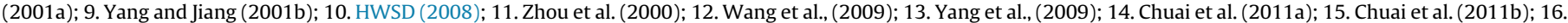

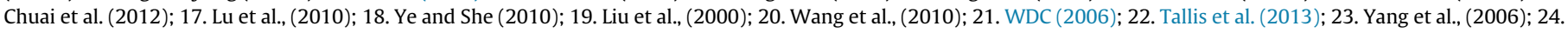
Zhang et al., (2011); 25. Chen et al., (2006); 26. Xue et al. (2006); 27. Zhao et al. (2012). 
$5.97 \mathrm{Tg} \mathrm{C}$, an average annual decrease of $2.5 \%$ (Fig. 2a). Carbon stocks contributed by forest land were negligible, owing to the very small percent of area involved. We can infer that distinct differences in the amount of carbon stored per unit area between urban land and green open spaces led to net losses in carbon stocks (Fig. 3). Average estimated carbon densities in Changzhou decreased from $71.31 \mathrm{Mg} \mathrm{C}^{-1}$ in 1986 to $49.88 \mathrm{Mg} \mathrm{C}^{-1}$ in 2011, and total carbon stocks decreased by about $30 \%$ from $11.50 \mathrm{Tg} C$ to $8.09 \mathrm{Tg} \mathrm{C}$. Average annual decrease in carbon densities (1.49 $\left.\mathrm{Mg} \mathrm{C} \mathrm{ha} \mathrm{yr}^{-1}\right)$ and total carbon stocks $\left(0.21 \mathrm{Tg} \mathrm{C} \mathrm{yr}^{-1}\right)$ were the greatest during the past decade due to intensified urban land use and cover change.

\subsection{Effects of land use and cover change on biomass and soil carbon stocks}

Aboveground and belowground biomass carbon stocks decreased by about $45 \%$ from $0.78 \mathrm{Tg} C$ to $0.43 \mathrm{Tg} C$, and soil carbon stocks decreased by about 30\% from $10.71 \mathrm{Tg} C$ to $7.66 \mathrm{Tg} C$ during the study period (Fig. 2b). Despite the magnitude of losses in soil

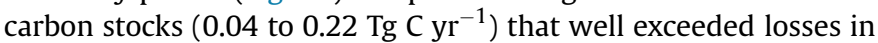

biomass carbon stocks ( 0 to $0.03 \mathrm{Tg} C \mathrm{yr}^{-1}$ ), average annual decrease in soil carbon stocks was only 0.3 to $2.6 \%$ compared to 0.5 to $5.1 \%$ annual losses in biomass carbon stocks (Table 2a). Although losses in soil carbon stocks were greater in Changzhou, urban land use and cover change disturbed to a greater extent in biomass carbon stocks.

\subsection{Effects of land use and cover change on carbon stocks in the urban center and peri-urban areas}

Average estimated carbon densities in the urban center were only 29.41 to $65.59 \mathrm{Mg} \mathrm{C} \mathrm{ha}^{-1}$ due to large areas of urban land, smaller than carbon densities ( 50.35 to $72.89 \mathrm{Mg} \mathrm{C}^{-1}$ ) in periurban areas. Total carbon stocks in the urban center were 0.11 to $0.32 \mathrm{Tg} C$, much smaller than carbon stocks ( 2.41 to $7.50 \mathrm{Tg} C$ ) in peri-urban areas. Average annual decrease in carbon densities was 1.03 to $1.19 \mathrm{Mg} \mathrm{C} \mathrm{ha}^{-1} \mathrm{yr}^{-1}$ in the urban center compared to 0.70 to $0.88 \mathrm{Mg} \mathrm{C} \mathrm{ha}^{-1} \mathrm{yr}^{-1}$ in peri-urban areas from 1986 to 2011 . Losses in total carbon stocks in the urban center were only 0 to $0.01 \mathrm{TgC}^{-1}$, much smaller than losses in carbon stocks $(0.03$ to $0.09 \mathrm{Tg} \mathrm{C} \mathrm{yr}^{-1}$ ) from peri-urban areas (Table $2 \mathrm{~b}$ ). Although there
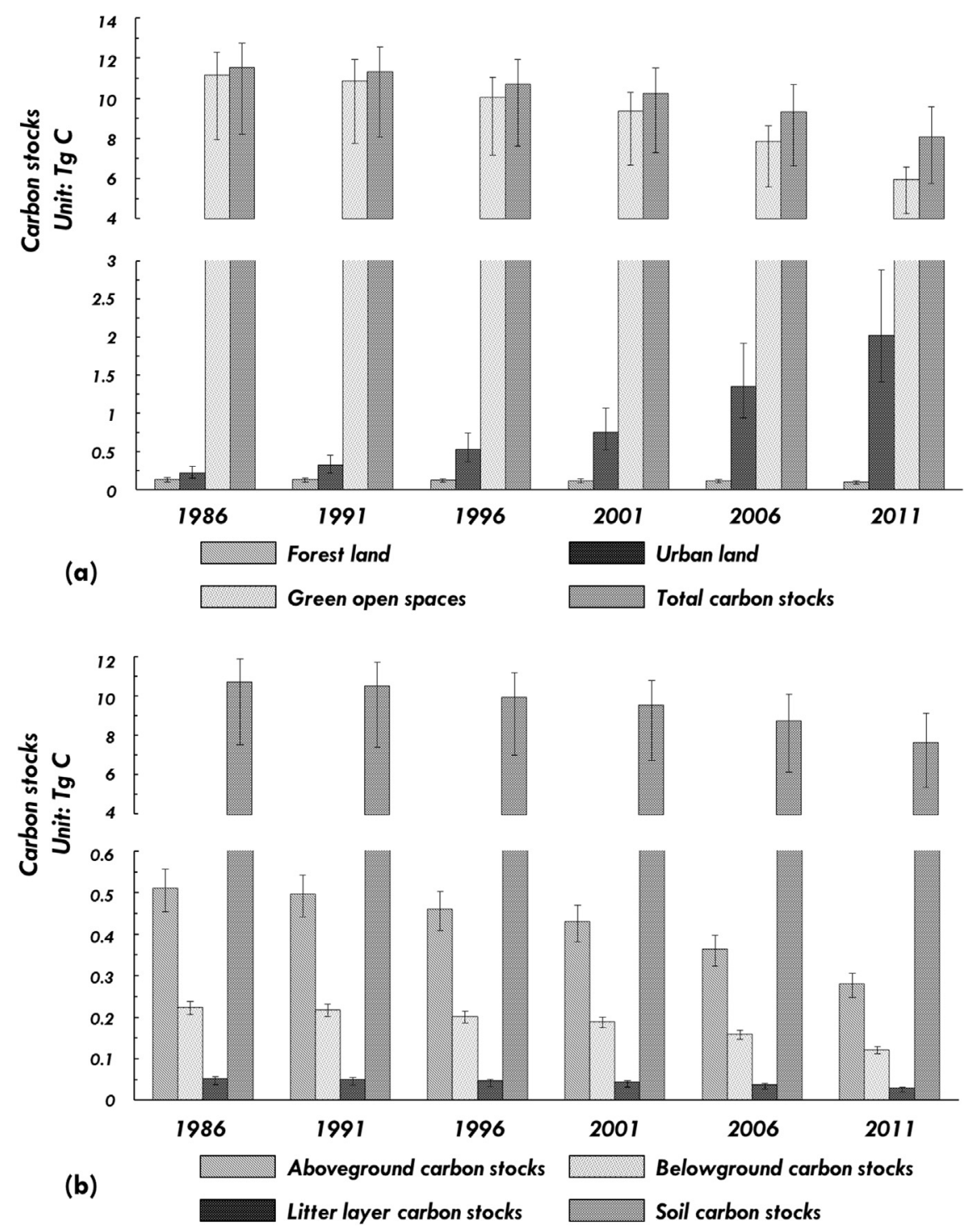

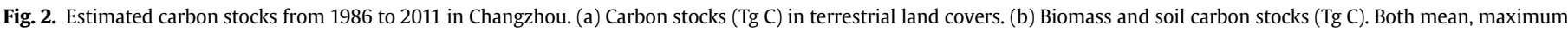
and minimum values of carbon stocks are shown in the figure. 

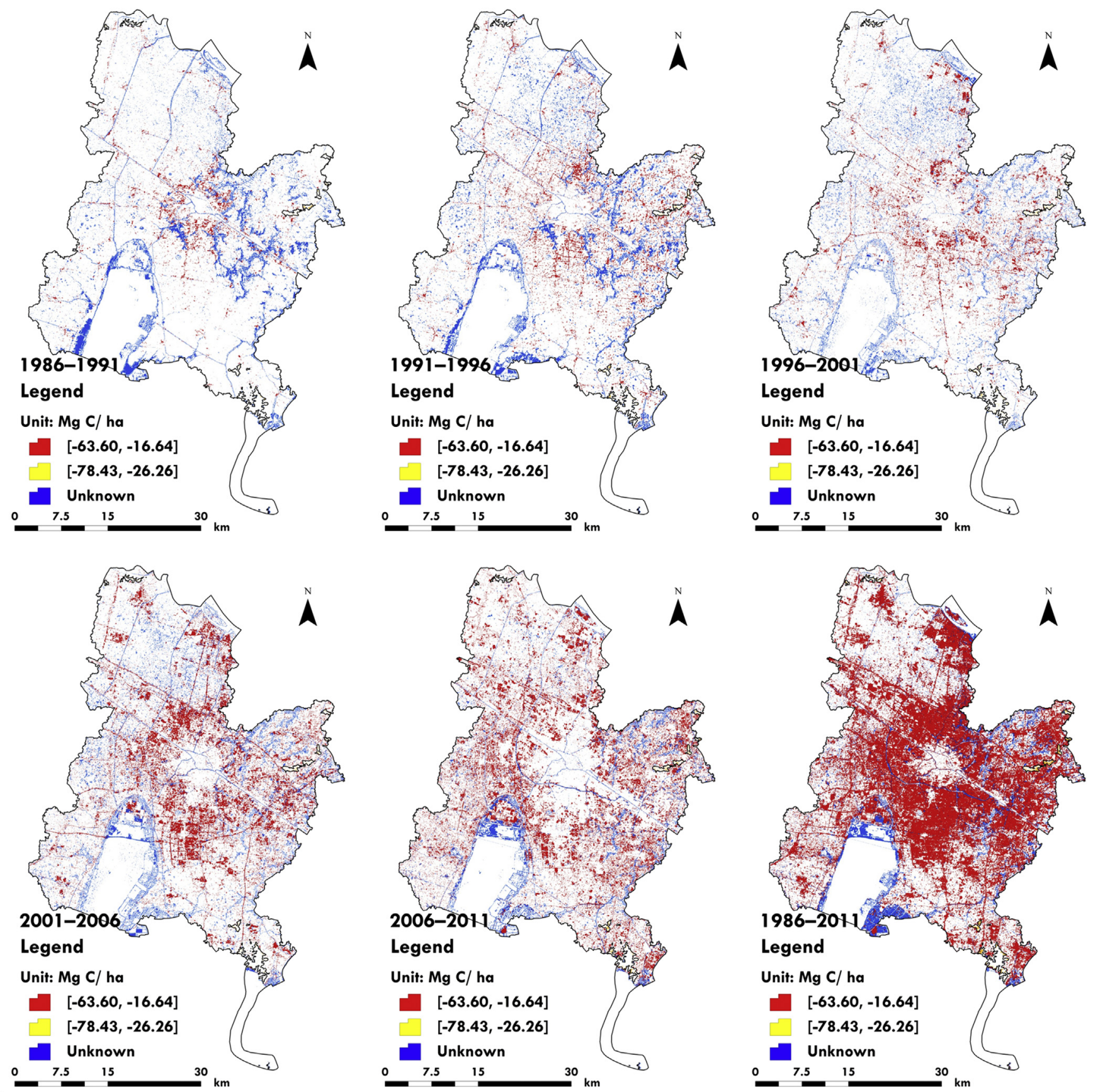

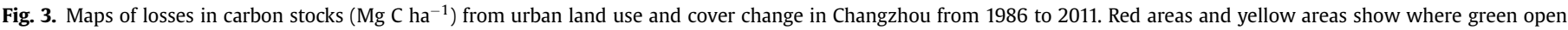
spaces and forest land were replaced by urban land, respectively. Blue areas are transitional areas between land and water.

was an intensified decrease in carbon densities in the urban center, losses in total carbon stocks were much greater from peri-urban areas. Carbon stored in peri-urban areas was much more sensitive to urban land use and cover change than carbon stored in the urban center of Changzhou.

\section{Discussion}

\subsection{Comparing estimated carbon stocks with other studies}

Biomass carbon stocks in forest land of Changzhou (averaged $24.75 \mathrm{Mg} \mathrm{C} \mathrm{ha}{ }^{-1}$ ) were comparable to those in the forest land of other cities in southern Jiangsu Province (21.23 to $21.56 \mathrm{Mg} \mathrm{Cha}^{-1}$ ), indicating that our estimates were reliable and consistent with already published studies (Zhao et al., 2010). On the other hand, our estimates of biomass carbon stocks were smaller than biomass carbon (55.37 $\mathrm{Mg} \mathrm{C} \mathrm{ha}{ }^{-1}$ ) stored in a natural forest near to the study area (Zhao et al., 2010). This was not only because of forest structure mainly comprised of young and middle-aged trees, which resulted in restrained biomass of a single tree, but also because of reduced tree densities of the whole forest due to human disturbances such as forest harvesting in the study area.

\subsection{Comparing losses in carbon stocks from land use and cover change and fossil fuels consumption}

Average annual carbon emissions from fossil fuels consumption were calculated from statistical data provided by Changzhou 
Table 2

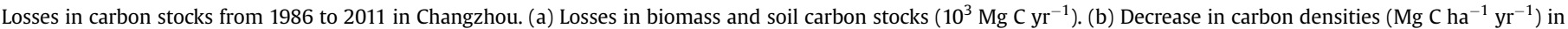

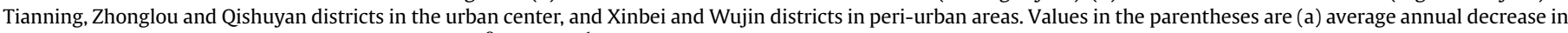
carbon stocks (\%), and (b) losses in carbon stocks $\left(10^{3} \mathrm{Mg} \mathrm{C} \mathrm{yr}^{-1}\right)$.

\begin{tabular}{|c|c|c|c|c|c|}
\hline (a) & $\begin{array}{l}\text { Aboveground biomass } \\
\text { carbon losses }\end{array}$ & & $\begin{array}{l}\text { Belowground biomass } \\
\text { carbon losses }\end{array}$ & $\begin{array}{l}\text { Litter layer } \\
\text { carbon losses }\end{array}$ & $\begin{array}{l}\text { Soil organic } \\
\text { carbon losses }\end{array}$ \\
\hline 1986-1991 & $-2.8(-0.5)$ & & $-1.2(-0.5)$ & $-0.3(-0.5)$ & $-36.6(-0.3)$ \\
\hline 1991-1996 & $-7.3(-1.5)$ & & $-3.2(-1.5)$ & $-0.7(-1.5)$ & $-112.0(-1.1)$ \\
\hline 1996-2001 & $-6.1(-1.4)$ & & $-2.7(-1.4)$ & $-0.6(-1.3)$ & $-81.7(-0.8)$ \\
\hline $2001-2006$ & $-13.1(-3.3)$ & & $-5.8(-3.3)$ & $-1.3(-3.1)$ & $-162.7(-1.8)$ \\
\hline $2006-2011$ & $-16.9(-5.1)$ & & $-7.4(-5.2)$ & $-1.7(-5.0)$ & $-217.7(-2.6)$ \\
\hline 1986-2011 & $-9.2(-2.4)$ & & $-4.1(-2.4)$ & $-0.9(-2.3)$ & $-122.1(-1.3)$ \\
\hline (b) & $\begin{array}{l}\text { Tianning district } \\
\text { carbon losses }\end{array}$ & $\begin{array}{l}\text { Zhonglou district } \\
\text { carbon losses }\end{array}$ & $\begin{array}{l}\text { Qishuyan district } \\
\text { carbon losses }\end{array}$ & $\begin{array}{l}\text { Xinbei district } \\
\text { carbon losses }\end{array}$ & $\begin{array}{l}\text { Wujin district } \\
\text { carbon losses }\end{array}$ \\
\hline 1986-1991 & $-1.05(-4.6)$ & $-0.81(-4.5)$ & $-0.49(-3.8)$ & $-0.17(-10.3)$ & $-0.18(-38.2)$ \\
\hline 1991-1996 & $-0.64(-3.7)$ & $-0.65(-4.7)$ & $-0.58(-2.1)$ & $-0.41(-44.1)$ & $-0.53(-73.0)$ \\
\hline 1996-2001 & $-0.91(-5.0)$ & $-0.93(-6.4)$ & $-0.69(-1.9)$ & $-0.45(-15.4)$ & $-0.54(-62.3)$ \\
\hline $2001-2006$ & $-1.45(-7.7)$ & $-2.25(-15.1)$ & $-1.71(-4.6)$ & $-1.24(-37.9)$ & $-1.39(-117.7)$ \\
\hline 2006-2011 & $-1.09(-6.7)$ & $-1.32(-9.0)$ & $-2.18(-7.0)$ & $-1.22(-47.4)$ & $-1.77(-173.7)$ \\
\hline 1986-2011 & $-1.03(-5.5)$ & $-1.19(-7.9)$ & $-1.13(-3.1)$ & $-0.70(-26.9)$ & $-0.88(-93.0)$ \\
\hline
\end{tabular}

Statistical Bureau, yielding a total of $73.92 \mathrm{Tg}$ C from 1986 to 2011 with annual rates averaging 0.80 to $6.55 \mathrm{Tg} \mathrm{C} \mathrm{yr}^{-1}$. In contrast, losses in carbon stocks from land use and cover change during the same period were $3.41 \mathrm{Tg} \mathrm{C}$, and annual rates were 0.04 to $0.24 \mathrm{Tg} \mathrm{C} \mathrm{yr}^{-1}$. Although losses in carbon stocks from land use and cover change amounted to about 4 to $8 \%$ of carbon emissions from fossil fuels consumption, this dramatic shift in land covers resulted in a decrease of about 30\% in total carbon stocks during the past several decades. It is clear that urban land use and cover change is not only a driving force of urban carbon emissions, but also a key factor affecting carbon dynamics at citywide and regional scales and climate change at a global scale.

\subsection{Limitations of the study}

The results of monitoring and assessment of Changzhou's carbon dynamics in response to urban land use and cover change depend greatly on accuracy of Landsat image interpretation and reliability of estimation of carbon stocks (Muñoz-Rojas et al., 2011). This approach does not tend to provide with accurate absolute values but it is meaningful in relative terms allowing comparing biomass and soil carbon stocks in different land covers and quantifying losses in carbon stocks from urban land use and cover change. Limitations of the InVEST model used in this research include a simplified urban carbon cycle, the inability to estimate carbon stocks in water area (Tallis et al., 2013) and the resulting unknown carbon dynamics in the transitional areas between land and water (Fig. 3). In future research, it will be necessary to obtain a better description of the pattern of land covers, to obtain more accurate carbon storage values in these land covers during each time period, and to quantify gradient change in terrestrial carbon stocks in response to urban land use and cover change (Alberti and Hutyra, 2009; Hutyra et al., 2011b; Ren et al., 2011).

\subsection{Implications of the results}

In this study, we used the InVEST model to monitor and assess the effects of urban land use and cover change on spatial and temporal variation in terrestrial carbon stocks in Changzhou based on both accurate spatial datasets and reliable estimates of biomass and soil carbon stocks. We found that urban land use and cover change created hotspots for losses in carbon stocks (Fig. 3). Total carbon stocks in Changzhou decreased by about
$30 \%$ in the past 25 years, an average annual decrease of $1.5 \%$. As recent growth trends continued, the expansion of urban land markedly decreased areas previously dominated by green open spaces, making urban land use and cover change and losses in carbon stocks an increasingly important component of regional carbon dynamics.

Our results suggest potential policy measures to mitigate losses in carbon stocks from urban land use and cover change for Changzhou and other fast-growing cities in China. Impervious surfaces in existing urbanized areas such as parking lots, public squares and pavements can be replaced by vegetated surfaces (e.g., bricks with gaps between them that allow growth of herbaceous plants with belowground biomass stored in root system) to mitigate negative effects of soil sealing on accumulation of soil organic carbon. Roof gardens on top of buildings provide valuable places for distribution of limited urban green spaces, thereby greatly increasing urban biomass. On the other hand, legislation should be implemented to protect green open spaces and forest land and preserve soil carbon stocks from expansion of urban land in rapidly urbanizing areas. Green belts in these areas not only serve as buffer zones that help to control expansion of urban land, but also serve as the key components capable of storing large amounts of biomass carbon over time.

\section{Acknowledgments}

This research was funded by the National Natural Science Foundation of China (No. 71273254, 71033005). The datasets used for estimating biomass and soil carbon stocks were provided by the Renewable Resources and Environmental Science Data Center for West China, Data Sharing Infrastructure of Earth System Science (http://www.geodata.cn), and by the Environmental and Ecological Science Data Center for West China, National Natural Science Foundation of China (http://westdc.westgis.ac.cn). We thank Becky Stewart, a native English speaking scientific editor, for her constructive suggestions for correcting and polishing the manuscript.

\section{Appendix A. Supplementary data}

Supplementary data related to this article can be found at http:// dx.doi.org/10.1016/j.jclepro.2014.07.055. 


\section{References}

Alberti, M., Hutyra, L., 2009. Detecting carbon signatures of development patterns across a gradient of urbanization: linking observations, models, and scenarios. In: Fifth Urban Research Symposium, Marseilles, France.

Borjesson, Pal, Tufvesson, L.M., 2011. Agricultural crop-based biofuels - resource efficiency and environmental performance including direct land use changes. J. Clean. Prod. 19, 108-120.

Cantarello, E., Newton, A.C., Hill, R.A., 2011. Potential effects of future land-use change on regional carbon stocks in the UK. Environ. Sci. Pol. 14, 40-52.

Castanheira, E.G., Freire, F., 2013. Greenhouse gas assessment of soybean production: implications of land use change and different cultivation systems. J. Clean. Prod. 54, 49-60.

Chan, K.M.A., Shaw, M.R., Cameron, D.R., Underwood, E.C., Daily, G.C., 2006. Conservation planning for ecosystem services. PLoS. Biol. 4, 2138-2152.

Churkina, G., Brown, D.G., Keoleian, G., 2010. Carbon stored in human settlements: the conterminous United States. Glob. Change. Biol. 16, 135-143.

Daily, G.C., Polasky, S., Goldstein, J., Kareiva, P.M., Mooney, H.A., Pejchar, L. Ricketts, T.H., Salzman, J., Shallenberger, R., 2009. Ecosystem services in decision making: time to deliver. Front. Ecol. Environ. 7, 21-28.

Davies, Z.G., Edmondson, J.L., Heinemeyer, A., Leake, J.R., Gaston, K.J., 2011. Mapping an urban ecosystem service: quantifying above-ground carbon storage at a citywide scale. J. Appl. Ecol. 48, 1125-1134.

Dhakal, S., 2010. GHG emissions from urbanization and opportunities for urban carbon mitigation. Curr. Opin. Environ. Sustain 2, 277-283.

Flysjo, A., Cederberg, C., Henriksson, M., Ledgard, S., 2012. The interaction between milk and beef production and emissions from land use change - critical considerations in life cycle assessment and carbon footprint studies of milk. J. Clean. Prod. 28, 134-142.

Goldstein, J.H., Caldarone, G., Duarte, T.K., Ennaanay, D., Hannahs, N., Mendoza, G., Polasky, S., Wolny, S., Daily, G.C., 2012. Integrating ecosystem-service tradeoffs into land-use decisions. Proc. Natl. Acad. Sci. USA 109, 7565-7570.

Guo, Z., Hu, D., Zhang, F.H., Huang, G.L., Xiao, Q., 2014. An integrated material metabolism model for stocks of urban road system in Beijing, China. Sci. Total. Environ. 470-471, 883-894.

Hortenhuber, S., Piringer, G., Zollitsch, W., Lindenthal, T., Winiwarter, W., 2014. Land use and land use change in agricultural LCAs and carbon footprints - the case for regionally specific LUC versus other methods. J. Clean. Prod. 73, 31-39.

Hutyra, L.R., Yoon, B., Cymerman, J.H., Alberti, M., 2011a. Carbon consequences of land cover change and expansion of urban lands: a case study in the Seattle metropolitan region. Landsc. Urban. Plan. 103, 83-93.

Hutyra, L.R., Yoon, B., Alberti, M., 2011b. Terrestrial carbon stocks across a gradient of urbanization: a study of the Seattle, WA region. Glob. Change. Biol. 17, $783-797$.

HWSD, 2008. Harmonized World Soil Database. Food and Agriculture Organization of the United Nations.

Liu, C.F., Li, X.M., 2012. Carbon storage and sequestration by urban forests in Shenyang, China. Urban. For. Urban. Green. 11, 121-128.

Liu, L.C., Wu, G., Wang, J.N., Wei, Y.M., 2011. China's carbon emissions from urban and rural households during 1992-2007. J. Clean. Prod. 19, 1754-1762.
Muñoz-Rojas, M., De la Rosa, D., Zavala, L.M., Jordán, A., Anaya-Romero, M., 2011. Changes in land cover and vegetation carbon stocks in Andalusia, Southern Spain (1956-2007). Sci. Total. Environ. 409, 2796-2806.

Nelson, E., Mendoza, G., Regetz, J., Polasky, S., Tallis, H., Cameron, D.R., Chan, K.M.A., Daily, G.C., Goldstein, J., Kareiva, P.M., Lonsdorf, E., Naidoo, R., Ricketts, T.H., Shaw, M.R., 2009. Modeling multiple ecosystem services, biodiversity conservation, commodity production, and tradeoffs at landscape scales. Front. Ecol. Environ. 7, 4-11.

Ponsioen, T.C., Blonk, T.J., 2012. Calculating land use change in carbon footprints of agricultural products as an impact of current land use. J. Clean. Prod. 28, 120-126.

Qiu, J.X., Turner, M.G., 2013. Spatial interactions among ecosystem services in an urbanizing agricultural watershed. Proc. Natl. Acad. Sci. USA 110, 12,149-12,154.

Raciti, S.M., Hutyra, L.R., Finzi, A.C., 2012. Depleted soil carbon and nitrogen pools beneath impervious surfaces. Environ. Pollut. 164, 248-251.

Ren, Y., Wei, X., Wei, X.H., Pan, J.Z., Xie, P.P., Song, X.D., Peng, D., Zhao, J.Z., 2011. Relationship between vegetation carbon storage and urbanization: a case study of Xiamen, China. For. Ecol. Manage 261, 1214-1223.

Seto, K.C., Güneralp, B., Hutyra, L.R., 2012. Global forecasts of urban expansion to 2030 and direct impacts on biodiversity and carbon pools. Proc. Natl. Acad. Sci. USA 109 (40), 16,083-16,088.

Strohbach, M.W., Haase, D., 2012. Above-ground carbon storage by urban trees in Leipzig, Germany: analysis of patterns in a European city. Landsc. Urban. Plan. 104, 95-104.

Sun, M.X., Yuan, Y., Zhang, J.Y., Wang, R.Q., Wang, Y.T., 2014. Greenhouse gas emissions estimation and ways to mitigate emissions in the Yellow River Delta High-efficient Eco-economic Zone, China. J. Clean. Prod., 1-14.

Tallis, H.T., Ricketts, T., Guerry, A.D., Wood, S.A., Sharp, R., Nelson, E., Ennaanay, D., Wolny, S., Olwero, N., Vigerstol, K., Pennington, D., Mendoza, G., Aukema, J., Foster, J., Forrest, J., Cameron, D., Arkema, K., Lonsdorf, E., Kennedy, C., Verutes, G., Kim, C.K., Guannel, G., Papenfus, M., Toft, J., Marsik, M., Bernhardt, J., Griffin, R., Glowinski, K., Chaumont, N., Perelman, A., Lacayo, M., Mandle, L. Griffin, R., Hamel, P., Chaplin-Kramer, R., 2013. InVEST 2.6.0 User's Guide. The Natural Capital Project, Stanford.

Wade, T.G., Wickham, J.D., Zacarelli, N., Riitters, K.H. 2009. A multi-scale method of mapping urban influence. Environ. Modell. Softw. 24, 1252-1256.

Wang, Z.H., Yang, L., 2014. Indirect carbon emissions in household consumption: evidence from the urban and rural area in China. J. Clean. Prod., 1-10.

WDC, 2006. Agricultural Photosynthetic-thermal Productivity in China (1 Km Resolution). Renewable Resources and Environmental Science Data Center for West China, Data Sharing Infrastructure of Earth System Science.

Zhang, C., Tian, H.Q. Chen, G.S., Chappelka, A., Xu, X.F., Ren, W., Hui, D.F., Liu, M.L. Lu, C.Q., Pan, S.F., Lockaby, G., 2012. Impacts of urbanization on carbon balance in terrestrial ecosystems of the Southern United States. Environ. Pollut. 164, 89-101.

Zhao, D., Li, F., Wang, R.S., Yang, Q.R., Ni, H.S., 2012. Effect of soil sealing on the microbial biomass, $\mathrm{N}$ transformation and related enzyme activities at various depths of soils in urban area of Beijing, China. J. Soils. Sediments 12, 519-530.

Zhao, M., Kong, Z.H., Escobedo, F.J., Gao, J., 2010. Impacts of urban forests on offsetting carbon emissions from industrial energy use in Hangzhou, China. J. Environ. Manage 91, 807-813. 